\title{
6331 Sayılı iSG Kanunu Uyarınca Kamu Sektöründe İşverenin Yükümlükleri, Kütahya Dumlupınar Üniversitesi’nde İş Sağlığı ve Güvenliği Uygulamaları
}

\author{
Employer's Obligations In The Public Sector In Accordance With The Occupational \\ Health Law No. 6331, Occupational Health and Safety Services Practices at \\ Kütahya Dumlupınar University
}

Bülent BÜYÜKKIDAN (D) , Hüseyin GÜMÜş

ÖZET

6331 Sayılı İş Sağlığı ve Güvenliği Kanunu, kamu sektöründe ve özel sektörde faaliyet gösteren işyerlerinde çalışanların sağlığını tehdit eden unsurların belirli bir sistematikle ele alınmasını gerektirmektedir. Sağlık gözetimi, mesleki yeterlilik, risk değerlendirmesi ve eğitim gibi birçok uygulamadan oluşan yeni sisteme uyum sorunları yaşanmaktadır. Bu çalışmada, Kütahya Dumlupınar Üniversitesinde (Kütahya DPÜ) yürütülmekte olan İş Sağlığı ve Güvenliği (İSG) uygulamalarının nitel değerlendirmesi yapılmıştır. İşverenin sorumluluklarının daha iyi anlaşılması için üniversitelerde yürütülen uygulamalar ve İSG yükümlülükleri belirtilmiștir.6331 sayılı ISG Kanununun gerektirdiği organizasyon, yasal-idari düzenlemeler ve üniversite içi çalışmaların güvenli bir șekilde yürütülmesi için risk yönetimi hakkında bilgi verilmiş ve bu kapsamda Kütahya DPÜ'de alınan tedbirler izah edilmiştir. Kütahya DPÜ ISG birimi oluşturulmadan önce kaza ve ramak kala olaylar için kaydedilen 759, 1230 ve 879 olan vahim, büyük ve orta risk skorlarının İSG çalıșmaları sonucunda 240, 282 ve $366^{\prime}$ ya düștüğü görülmüştür. Kütahya DPÜ'de İSG işlerini konu alan bu çalıșma, kamu ve özel sektör kuruluşlarına iş sağlığı ve güvenliği uygulamalarının önemini göstermesi açısından örnek niteliğindedir.

Anahtar Kelimeler: İş Sağlığı ve Güvenliği Kanunu, Kamu Kurumu, İş Kazası

\section{ABSTRACT}

The occupational health and safety law numbered 6331 requires that the factors threatening the health of employees in the public and private sector workplaces should be systematically addressed. Adaptation problems to the new system consisting of many applications such as health surveillance, professional competence, risk assessment and training are experienced. In this study, qualitative evaluation of Occupational Health and Safety (OHS) practices carried out at Kütahya Dumlupınar University (Kütahya DPÜ) was made. To better understand the employer's responsibilities, practices carried out at universities and OHS obligations are specified. Information was given about the organisation required by the OHS Law No. 6331, legal-administrative regulations and risk management in order to carry out the works within the university in a safe way and the measures taken in Kütahya DPU were explained in this context. It was observed that the grave, large and medium risk scores of 759, 1230 and 879 recorded for accidents and near-miss incidents before the Kütahya DPÜ OHS unit was established decreased to 240, 282 and 366 as a result of the OHS studies. This study, which focuses on OHS affairs in Kütahya DPU, is an example in terms of showing the importance of occupational health and safety practices for public and private sector organizations.

Keywords: Occupational Health and Safety Law, Public Institution, Occupational Accident.

Bülent BÜYÜKKIDAN | bulent.buyukkidan@dpu.edu.tr

Kütahya Dumlupınar Üniversitesi, Fen-Edebiyat Fakültesi, Kimya Bölümü, Kütahya, Türkiye

Kütahya Dumlupinar Üniversity, Faculty of Arts and Sciences, Chemistry Department, Kütahya, Turkey

Hüseyin GÜMÜş I huseyin.gumus@bilecik.edu.tr | Sorumlu Yazar/Corresponding Author

Bilecik Şeyh Edebali Üniversitesi Osmaneli Meslek Yüksekokulu İş Sağlığı ve Güvenliği Programı, Bilecik, Türkiye

Bilecik Seyh Edebali Üniversity, Osmaneli Vocational School, Occupational Health and Safety Program, Bilecik, Turkey

Received/Geliş Tarihi : 16.03.2020

Accepted/Kabul Tarihi: 02.12.2020 


\section{GIIRIŞ}

İnsan gücünün yerine makinelerin geçmeye başladığı Sanayi Devrimi ilk aşamada insana daha rahat bir hayat süreceğini ve kas gücüyle yapmak zorunda kaldığı işleri makinelere devredeceğini hayal ettirmiştir. Ancak makineleşmeyle birlikte iş gücü gereksinimi ve yıpranma daha da artmıştır [1]. Bu nedenle çalışan sağlığının korunmasına yönelik çeşitli düzenlemelerin yapılması gerekli görülmüştür. Ortaya çıkan iş imkanlarının barındırdığı tehlikelerden çalşsanların sağlığını korumak için yeni tehlikeler göz önünde bulundurulmalıdır. Bu kapsamda etkili düzenlemelerin sanayi devrimi sonrasında Dünya Sağlık Örgütü (WHO) ve Uluslararası Çalışma Örgütü (ILO) gibi uluslararası düzeyde kabul görmüş kuruluşların öncülügünde geliştiği anlaşılmaktadır [2-4]. Osmanlı devletinde, Fütüvvetname olarak adlandırılan zanaatkarların sağlıkları ile ilgili uygulamaların yer aldığı ticari kurallar, 1865 tarihli Dilaver Paşa Nizamnamesi maden işçileri için çıkartılmış olup, 1869 tarihli Maadin Nizamnamesi de çalışanların sağlığını korumak için oluşturulmuş bazı yazılı düzenlemelerdir. Cumhuriyetle birlikte çıkartılan Ulusal Bayram ve Genel Tatiller Kanunu ve Borçlar Kanunu çalışanların bazı haklarını düzenleyici niteliktedir. 1930 tarihinde çkartılan 1593 sayılı Umumi Hıfzı-Sıhha Kanunu, 3008 Sayılı İş Kanunu, 12586 sayılı Deniz İş Kanunu, 1971 yılında çıkartılan 1475 Sayılı İş Kanunu, 2003 yılında Avrupa Birliği uyum sürecinde kabul edilen yeni 4857 sayılı İş Kanunu Türkiye'de kabul edilen çalışma ve iş̧̧i ile ilgili kanunlardır. 20 Haziran 2012 tarihinde kabul edilen 6331 sayılı İş Sağlığı ve Güvenliği Kanunuyla çalışan haklarının ve sağlığının korunması, çalışma ortamında sağlık ve güvenlik uygulamalarına yeni bir boyut kazandırmıştır [3]. BS8800, OHSAS18001 ve Avrupa Normlarının (EN) incelenmesi ve uyarlanmasıyla elde edilmiş yeni yasal düzenleme, bir anlamda bugüne kadar Türkiye'de hazırlanmış en kapsamlı ve uygulanabilir içeriğe sahiptir [5].

Dünya ve Avrupa sıralamasında iş kazalarının sayısı ve oranı bakımından üst sıralarda yer alan Türkiye'de ölüm, ağır yaralanma ve maddi hasar gibi yüksek maliyetli iş kazaları, iş yerlerinde sağlık ve güvenliğin sağlanması önemini arttırmaktadır. Örnek olarak 2016 yılında Türkiye'de iş kazası geçiren sigortalı sayısı 286.068, iş kazası sonucu ölen sigortalı sayısı 1405 , kamuda iş kazası sayısı 18.017 olarak kayıtlara geçmiştir [6]. 2017 yılında 99 sektörde 5510 sayılı Kanun'un 4-1/a maddesi kapsamındaki sigortalılardan iş kazası geçiren ve meslek hastalığına tutulan sigortalı sayılarının ekonomik faaliyet sınıflamasına ve cinsiyete göre dağılımına bakıldığında 300.770 erkek, 58.883 kadın iş kazası geçirmiş veya meslek hastalığına yakalanmıştır [7].

İSG Kanun kapsamı tanımında Md-2(1) "Bu Kanun; kamu ve özel sektöre ait bütün işlere ve işyerlerine, bu işyerlerinin işverenleri ile işveren vekillerine, çurak ve stajyerler de dahil olmak üzere tüm çalı̧̧anlarına faaliyet konularına bakılmaksızın uygulanır" ifadesi kanun kapsamının genişliğini ifade etmekte; alışılmışın dışında bir sağlık ve güvenlik politikasını zorunlu kılmaktadır [8]. Sektörlerin yaptıkları işlere göre tehlike sınıflarının belirlenmesi ve yapılacak İSG işlerinin bu sınıflamaya göre ayrılması gerekmektedir. Kamu sektörü genellikle ofis-yazılım-evrak işlerinin yapıldığı, tehlikelerin ağır sanayi ve tarım işlerine göre daha az olduğu bir ortam olarak algılanmaktadır. Ancak bu çalışmada ele alınan ve yaptığı ana iş kolu eğitim olduğu için az tehlikeli grupta yer alan bir Üniversite Yerleşkesinde 6331 sayılı İSG Kanunu doğrultusunda yürütülen İSG hizmetlerinden de anlaşılacağı üzere, yüksek riskli işler de yapılmaktadır [9]. Kimya ve biyokimya laboratuvarları, patlayıcı-yanıcı gazlar, metal işlerinin yapıldığı atölyeler, kanalizasyon ve sıhhi tesisat işleri, elektrik işleri üniversite bünyesinde bulu- 
nan çok riskli iş gruplarına örneklerdir [10]. Yeni İSG mevzuatına teknik ve sağlık personeli eksikliği, çalışanların ve işverenin konu hakkındaki yetersizlikleri gibi nedenlerle uyum zorluğu yaşayan kurumlar, bünyesinde bulundurdukları çok riskli işlerin sorumluluğunu da üstlenmiş durumdadırlar. Yeni uygulamanın avantajlarının yanında sağlık sektörüne getirdiği yükümlülüklerle para cezalarının arttığı, risk değerlendirmesinde büyük zorluklar yaşandığı kaydedilmiştir. Sağlık sektörünün çok riskli grupta yer alması hasta çalışan ve tesis güncelliği konularında ekstra önlemlere gerek duyulması diğer uygulama zorluklarındandır [11, 12]. Bir diğer araştırmada ortaöğretim kurumlarında İSG ile ilgili okul müdürlerinin uygulamaya bakışları değerlendirilmiştir. İSG uygulamalarında sorumluluğun eşit dağıtılması yerine işveren konumundaki okul müdürlerine yüklenmesi ve uzmanlık alanları olmadığı halde binaların yapısal risklerini değerlendirmek zorunda kalmaktan mağdur oldukları belirtilmiştir [13]. İş kazası "İş yerinde veya işin yürütümü nedeniyle meydana gelen, ölüme sebebiyet veren veya vücut bütünlïğ̈̈nü ruhen ya da bedenen engelli hale getiren olay" meslek hastalığı "Mesleki risklere maruziyet sonucu ortaya çıkan hastalı̆ğ gibi olumsuz durumlar" olarak tanımlanmakta ve genellikle çalışanların dikkatsizliği ve ihmalinin yanında çalışma mevzuatına uygun olmayan işveren tutumları da büyük sorun oluşturmaktadır. Özellikle resmi otoritelerin İSG alanındaki boşlukları yeteri kadar denetlemediği az gelişmiş toplumlarda, çalş̧anlar riskleri bilmesine rağmen ekonomik gereksinimden dolayı tehlikeli ortamda çalısmak zorunda kalabilmektedirler [14]. İş sağlığı ve güvenliği uygulamalarında hedef, "çalı̧sanın rubsal ve bedensel sağlığın tehdit eden her türlü unsurun belirlenerek giderilmesi veya en aza indirgenmesi için sistemli, planlı ve bilimsel çalışmalar yapmak" şeklinde tanımlanmaktadır [15]. Dolayısıyla tehlike sınıfı veya faaliyet alanı ne olursa olsun, bütün tehlikelerin belirlenerek en aza indiril- mesi için yeni düzenlemeler gerekmektedir [16]. Programlanmış uygulama adımları kanunda belirtilmiş olup, 40 'tan fazla yönetmeliklerle ayrıntılı izah edilmektedir. Daha önce uygulanmakta olan iş kanunlarından farklı olarak işveren, "şallşan istihdam eden gerçek veya tüzel kişi yahut tüzel kişiliği olmayan kurum ve kuruluşları", çalışan "Kendi özel kanunlarındaki statülerine bakılmaksızın kamu veya özel iş yerlerinde istihdam edilen gerçek kişiyi", çalışan temsilcisi "İs sağhlğ̆ ve güvenliği ile ilgili çalışmalara katılma, çalışmalart izleme, tedbir alınmasin isteme, tekliflerde bulunma ve benzeri konularda çalışanlar temsil etmeye yetkili çalı̧̧anı", iş güvenliği uzmanı "Usul ve esasları yönetmelikle belirlenen, iş sağglğg ve güvenliğgi alanında görev yapmak üzere Bakanlıkşa yetkilendirilmiş, iş güvenliği uzmanliğg belgesine sahip, Bakanlık ve ilgili kuruluşlarında çallşma hayatın denetleyen müfettişler ile mühendislik veya mimarlık eğitimi veren fakültelerin mezunlar ile teknik elemanı" çalışanların eğitimi, sağlık gözetimi, risk değerlendirmesi, İSG kurulları gibi kavramlar 6331 sayılı İSG Kanununda bir arada alınmışırı [17]. Ancak sistemin yeteri kadar benimsenmesi ve hassasiyetle yürütülmesi destekleyici bilimsel kaynak ve uygulama örnekleriyle sağlanabilir. Ghahrahmani ve Salminen çalışmalarında sadece OHSAS18001 sertifikasının alınmasının İSG kültürünün benimsenmesi anlamına gelmediğini, başarılı bir güvenlik uygulamasının gönüllü katılımla mümkün olabileceğini vurgulamışlardır [18].

$\mathrm{Bu}$ çalışmada İş Sağlığı ve Güvenliği Kanununun, ana faaliyet alanı eğitim olan Üniversitelerde uygulanmasına örnek, Kütahya Dumlupınar Üniversitesinde İSG birimi tarafından yürütülen faaliyetlere yer verilmesi amaçlanmaktadır. Kanunda zorunlu olarak yapılması istenilen İSG işleri başlıklar halinde açıklandıktan sonra, Üniversite biriminde düzenleme öncesi ve sonrasındaki durum fotoğraf, tablo ve ilgili evraklarla açıklanmaya çalışılacaktır. Bu çalışma 6331 sayılı İSG Kanunun gerektirdiği değişiklerin özet- 
lenmesi, kamu kurumlarında oluşturduğu algı ve Kütahya DPÜ'de meydana getirdiği değişimlerin derlemesinden oluşmakta olup, nitel gözlemlere ve değerlendirmeye dayanmaktadır.

\section{6331 SAYILI İSG KANUNU KAPSAMINDA YAPILAN DÜZENLEMELER}

Çalışanların sağlığının korunması için iş kazalarının engellenmesi yönünde alınan önlemler uzun vadede işletmeye ekstra maliyetler getiren zorunluluklar gibi görülmektedir. Ancak iş kazaları anlık dikkatsizlik ve küçük tedbirsizliklerden kaynaklandığı düşünüldüğünde bu önlemlerin gerekliliğinin ne kadar önemli olduğu daha iyi anlaşılmaktadır [19]. İş kazalarının bir ülkeye getirdiği sağlık giderleri, iş kaybı, ölüm ve iş göremezlik kaybı gibi etkilerinin ekonomik maliyeti İSG maliyetleriyle karşılaşıımalı olarak araştırılmış ve yüksek kaza maliyetlerindense kazaların önlenmesinin daha kârlı olduğu sonucuna varılmıştır [20]. İş sağlığı ve güvenliği uygulamaları gelişmiş ülkelerde ve uluslararası faaliyet gösteren büyük işletmelerde zorunluluktan ziyade bir kültür olarak algılanmaktadır [21]. Benzer algının Türkiye'de benimsetilmesi için çalışmalar devam etmektedir. Bu amaçla hazırlanan 6331 sayılı İş Sağlığı ve Güvenliği Kanunu 30/06/2012 tarihinde yayımlanmış ve 38. Madde ile yürürlüğe girme tarihleri düzenlenmiştir. Kısaca İş Güvenliği Uzmanı (İGU) ve İş Yeri Hekimi (İH) bulundurulmasını zorunlu kılan 6. ve 7. maddelerin yürürlüğe girmesi İSG kanunun yayım tarihinden, önce 6 ay sonraya ardından tekrar 2 yıl sonraya ertelenmiştir. Yapılan bazı değerlendirmeler sonucunda belirtilen maddelerin uygulanması önce 1 Temmuz 2017, sonra da 1 Temmuz 2020'ye ertelenmiştir. Bu erteleme Kamu Kurumlarının ve özellikle çalışan sayısı 50'den az olan küçük işletmelerin sisteme uyumunu kolaylaştırmak amacıyla yapılmıştır. Ancak bazı kuruluşlar bunu yanlış algılamış ve sisteme uyumlu hale gelmek için hiçbir girişimde bulunmamıştır [22]. İşs sağlığı ve güvenliği hizmetlerini (6. 7. ve İSG personellerinin çalışma usullerini belirleyen $8 . \mathrm{Md}$ ) içeren düzenlemeleri iş yerlerinde uygulamaya koyarak, İSG kültürünü yasal zorunluluk olmadan önce benimseyen Kütahya DPÜ'de bazı çalışmalar başlatılmıştır. 6331 sayılı İSG Kanununa göre DPÜ-İSG biriminin oluşturulması, görev tanımlarının yapılması ve diğer yükümlülükler şeklinde devam eden İSG uygulamalarının özeti Tablo:1 de verilmektedir [8].

\section{A. Kurumsal Yapılanma ve İdari Düzenlemeler ve Uy- gulamalar}

6331 Sayılı İş Sağlığı ve Güvenliği Kanunu kapsamında Kütahya Dumlupınar Üniversitesinde iş sağlığı ve güvenliği ile ilgili hazırlıkların yapılması mevzuattaki gerekliliklerin yerine getirilmesi ve birimler arası koordinasyonun sağlanması amacıyla kurumsal yapıda bazı düzenlemeler yapılmıştır. Bu çerçevede Kütahya DPÜ Senatosunun 30.07.2015 tarih ve 2015/10 sayılı kararı ile Rektörlük Makamına bağlı olarak,

a. İş Sağllğg ve Güvenliği Koordinatörlüğ̈̈ kurulmuş ve Koordinatörlük Koordinasyon Kurulu olușturulmuștur. Koordinatörlük kurulunun oluşturulmasından sonra mevzuatın gerekli kıldığı yapılanma ve idari düzenleme çalışmaları yapılmışıtır.

b. Koordinatörlük Yönergesi hazırlanıp Senatoda kabul edilerek yürürlüğe konulmuştur.

c. Akademik ve idari toplamda yaklaşık 2100 personeli bulunan Kütahya DPÜ'de, 50 ve üzeri çalışanı bulunan 13 birimde İs Sağlığı ve Güvenliği Kurulları (İSK), 50 'den az çalışanı olan birimlerde ise İSG birimleri oluşturulmuştur. Kurullarda görev alacak personelin görevlendirmesi yapılmış, oluşturulan İSG kurul toplantılarının en fazla 3 ayda bir periyodik olarak yapıl- 
ması sağlanmıştır.

d. Rektörlük yürütücülügün̈nde Kütahya DPÜ İSG Üst Kurulu olușturulmuştur. Şekil 1'de DPÜ'de İşs Sağlğ̆ı ve Güvenliği hizmetinin idari organizasyon şeması görülmektedir.

e. 50'den fazla çalışanı olan tüm kurullar ve 50'den az çalışanı olan birimler için is güvenliği uzmanı ve işyeri hekimi görevlendirmesi yapılmıştır. Üniversitelerin NACE kodunun az tehlikeli sınıfta olduğu da dikkate alınarak, Kütahya DPÜ’de iş güvenliği uzmanlığı sertifikasına sahip personellerin görevlendirilmesi yapılmıştır. Bunların dağılımı 2 tane A, 4 tane C sınıfı olmak üzere 4 tane akademik 2 tane idari personel iş güvenliği uzmanı, 1 tane akademik personel işyeri hekimi olarak yarım zamanlı olarak görevlendirilmiştir. Belirtilen kadroda 2 sene aktif görev yaptıktan sonra kamu görevlisi uzmanların ücretlendirmesindeki mevzuatın uygulanmasındaki ertelemeler sebebi ile 4 iş güvenliği uzmanı görevinden ayrılmışırı. Mevcut durumda işveren tarafından görevlendirilen 2 kişi tam zamanlı C sınıf iş güvenliği uzmanı İSG işlerini yürütmektedir.

f. 4857 sayllı İş Kanunu'nun 3'ncü maddesi hükmüne dayanılarak hazırlanan "Alt İşverenlik Yönetmeliği” kapsamındaki asıl işveren alt işveren ilişkisi temel alınarak, asıl işveren tarafından alt işverenlerin denetim, gözetiminin yapılması ve evrak eksikliklerinin tamamlanması ve alt işverenlerin sorumluluklarını yerine getirmesinin sağlanması amacıyla "İş Sağlığı ve Güvenliği Ek Sözleşmesi” hazırlanmıştır. Sözleşme Kütahya DPÜ İSG üst kurul onayıyla uygulamaya konularak tüm alt işverenlerle imzalanmıştır. Ayrıca sözleşmede belirtilen yükümlülüklerin aynı zamanda alt işverenlerle imzalanacak ana sözleşme hükümlerine eklenmesi konusunda görüş birliğine varılmıştır. Yapılan bu çalışmalarla so- rumlusu olunan alt işverenlerde yaşanabilecek İSG kaynaklı risklerin azaltılması sağlanmıştır.

g. Üniversite ve alt işveren çalışanlarının görev tanımına ve yetkinliğine uygun ișlerde çalıștırılmalarına yönelik kanun hükümlerinin hayata geçmesinin sağlanması (mesleki yeterlilik) amacılla, tüm birimlerin işveren veya vekilleri resmi olarak bilgilendirilmiştir. İş güvenliği uzmanları tarafından konu hakkında İSG kurullarında sunumlar yapılarak farkındalık sağlanmıştır.

h. Kütahya DPÜ İSG koordinatörlüğünde görevli iş güvenliği uzmanları sorumlu oldukları birimlerinde; 6331 iş sağlğ̆ı ve güvenliği kanunu ve yönetmelikleri kapsamında çalışmalar yapmakta (İSG hizmetleri) bu çerçevede tehlike sınıfına göre; düzenli aralıklarla kurul oluşturulan birimlerde, İSG kurul toplantılarını ve saha gözetimlerini inceler, kurul oluşmayan birimlerde ise saha gözetimlerini yürütür, alt işveren bulunan birimlerde de alt işverenle ilgili denetleme, takip uyarı ve bilgi temini çalışmalarını yürütmektedirler.

Şekil 1: İşs sağlığı ve güvenliği koordinatörlüğü organizasyon şeması.

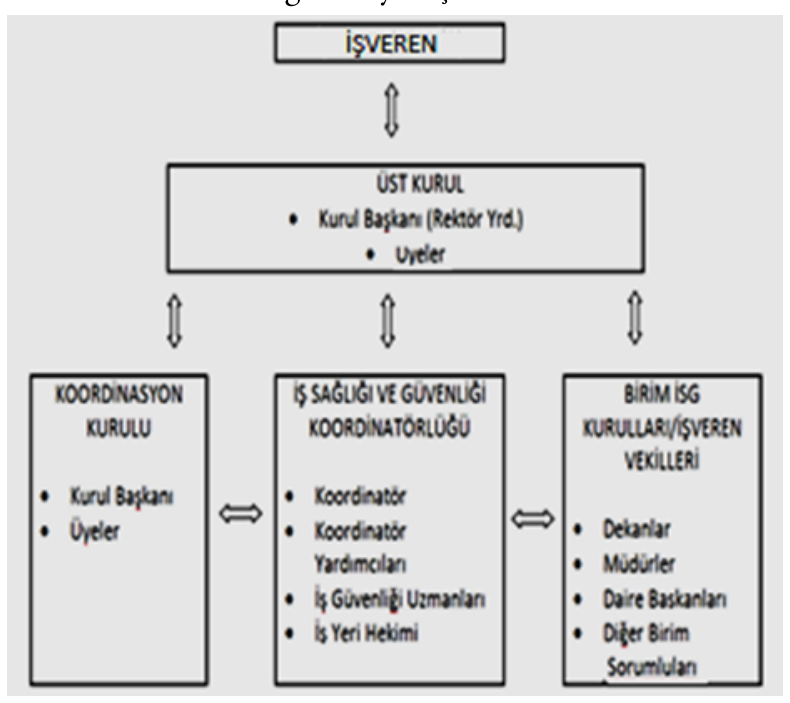


Tablo 1: 6331 sayılı İSG kanununda istenilen düzenlemeler ve Kütahya DPÜ’de yapılan değişiklikler.

\begin{tabular}{|c|c|}
\hline 6331 Sayılı isG Kanununda Istenilen Düzenleme (IIlgili Madde) & Kütahya DPÜ'de Yapılan Uygulama \\
\hline $\begin{array}{l}\text { Iş sağlığı ve güvenliği kurullarının oluşturmak ve koordinasyonu- } \\
\text { nu sağlamak } \\
\text { (md. 22, 23) }\end{array}$ & $\begin{array}{l}\text { IIA-a. İş Sağlığı ve Güvenliği Koordinatörlüğü kurulmuş ve Koordinatörlük } \\
\text { Koordinasyon Kurulu oluşturulmuştur. } \\
\text { IIA-b. Koordinatörlük Yönergesi hazırlanmış ve uygulamaya geçirilmiştir. } \\
\text { IIA-c. İş Sağlığı ve Güvenliği Kurulları (iSK), ve isG birimleri oluşturulmuştur. } \\
\text { IIA-d. Rektörlük iSG Üst Kurulu oluşturulmuştur. }\end{array}$ \\
\hline
\end{tabular}

IIB Risk değerlendirmesi çalışmaları aşağıdaki başlıklar altında yürütülmüştür.

Risk değerlendirmesi yapmak, riskleri analiz etmek, azaltmak veya ortadan kaldırmak (md. 4,5, 10)
IIB-1. Tehlikelerin belirlenmesi.

IIB-2. Risk analizleri ve değerlendirme.

IIB-3. Tehlike ve risk azaltma.

IIB-4. Hazırlık.

Çalışanlara eğitim vermek, çalışan temsilcisi seçmek, isG organizasyonu yapmak ve gerekli araç gereçleri bulundurmak (md. 5, 17)

IIA-e. İş güvenliği uzmanı ve iş yeri hekimi görevlendirmesi yapılmıştır.

Sağlık ve güvenlik koşullarını değişen şartlara uygun hale getirmek, mevcut durumu iyileştirmek, is tedbirlerini izlemek, denetlemek

(md. 6)

Ölçüm kontrol yapmak, tehlike sınıfinı belirlemek (md. 10, 9)

Çalışanları sağlık gözetimine tabi tutmak (md. 15)

IIA-h. ISG hizmetlerinin yürütülmesi sağlanmış, görevlendirmeler yapılmıştır.

Isıtma tesisatında gaz ve basınç ölçümleri yapılmıştır. Diğer ölçümler yönetmeliğe uygun olarak yapılmakta veya planlanmaktadır.

IIA-e. İş güvenliği uzmanı ve işyeri hekimi görevlendirmesi yapılmış, sağlık taraması uygulanmaktadır.

IIA-c. Birimlerde ilk yardım, arama kurtarma ve yangına müdahale ekipleri oluşturulmuş ve eğitimlerinin üniversitenin sertifikalı eğitim veren DPÜAFAMER merkezince sağlanmıştır.

Acil durum ve tahliye planları yapmak, tatbikat yapmak (md. 11)

IIB-4. Her birimde afet ve acil durum planları hazırlanarak, acil çıkışlar, acil toplanma merkezleri, sorumlu personel ve ekipman belirlenerek, personel bilgilendirilmiştir.

\footnotetext{
Yasal süreci içerisinde iş kazası ve meslek hastalığı bildirimi yapmak

(md. 14)
}

Çalışanlarını bilgilendirmek, iş sağlığı ve güvenliği eğitimlerini almasını sağlamak, mesleki eğitim almalarını sağlamak (md. 16, 17)
IV. Kaza yönetimi uygulamaları içinde, meydana gelen iş kazaları isG üst kurulu tutanaklarıyla 3 iş günü içinde SGK'ya bildirilmektedir.

IIA-g. Alt işveren çalışanlarının görev tanımına ve yetkinliğine uygun işlerde çalıştırılmalarına yönelik kanun hükümlerinin uygulanması sağlanmıştır (mesleki yeterlilik belgeleri için eğitim verilmiştir).

III-a. Görev yapmakta olan personelin temel isG eğitimleri almaları sağlanmıştır.

IIA-f. Asıl işveren alt işveren ilişkisini tanımlayıcı sözleşmeler düzenlenmiştir, bu sözleşmeler esas iş sözleşmesine eklenmiştir.

Çalışan temsilcisi ve sendika faaliyetleri önceki düzenlemelere göre devam etmektedir. Sendika temsilcisi ve faaliyetleri, temsilciliklerin tahsis edildiği birimlerinde yürütülmektedir.

Çalışanların psikososyal tehlikeler karşısında etkilenme seviyeleri ve korunmalarına yönelik anket çalışmaları devam etmektedir. 


\section{B. Risk Yönetimi Çalışmaları}

Kütahya DPÜ'de iş sağlığı ve güvenliği kapsamında uygulanan risk yönetimi çalışmalarının aşağıda belirtilen ana başlıklar altında yürütülmesi kararlaştırılmıştır.

B1. Tehlikelerin belirlenmesi

B2. Risk analizleri ve değerlendirme

B3. Tehlike ve risk azaltma

B4. Hazırlık

\section{B1. Tehlikelerin Belirlenmesi}

Risk yönetimi çalışmalarında tehlike ve risklerin belirlenmesinde bir özel firma tarafindan 2013 yılında yapılan risk analiz raporu esas alınmıştır. Bu rapora göre 2013 yılı itibarıla Kütahya DPÜ çalışma ortamında tespit edilen tehlikelerin miktarı ve kaynağına göre dağılımı Tablo 2'de sunulmuştur. Risk analiz raporlarına göre; Kütahya DPÜ'de 2013 yılı itibarıyla başlıca tehlike kaynaklarının sırasıyla yangın ve patlama oluşturabilecek tehlikeler, kimyasal ve biyolojik tehlikeler ile iş kazalarına neden olabilecek tehlikeler olarak sıralandığı dikkat çekmektedir. Bu tehlikelerin vahim ve büyük risk seviyesinde kazaya sebebiyet verecek riskler oluşturacağı bir gerçektir.

\section{B2. Risk Analizleri ve Değerlendirme Çalışmaları}

Bu aşamada, Kütahya DPÜ çalışma ortamlarında tespit edilen tehlikeler sonucu oluşabilecek riskler belirlenmiş ve bu risklerin $3 \mathrm{~T}$ metoduyla analizi ve değerlendirmesi yapılarak her tehlikenin risk seviyesi tespit edilmiş ve müdahale öncelikleri belirlenmiştir. 3T risk değerlendirme yöntemi birçok sektöre kolay uyum sağlayabilmesi ve aynı işyerinde çok değişik risk gruplarının bulunması durumunda uygulanan bir risk değerlendirme yöntemidir. Bu pratik özelliğiyle matris, finekinney ve diğer sık kullanılan yöntemlerden ayrışmaktadır. Bir işyerinde karşılaşma ihtimali olan risklerin, etkilerinin ve çözüm önerilerinin sıralı bir şekilde verildiği kontrol listesine benzemektedir. Olasılıkların tahmin edilmesi bu değerlendirmede ön planda tutulmaz. Çünkü tehlikeli bir durum gelecekte çalışan sağlığına yönelik bir sorun oluşturabilir. 3T yöntemine göre bunu değerlendirmek gereksiz olup, bu tehlikeli durumun giderilmesi için yapılması gereken çalışmalara odaklanılır. Sorun çıkmıyorsa kontrol önlemleri yeterli, ara sıra çıkıyorsa kontrol önlemleri arttırılmalı, sürekli sorun çıkan sistemlerde önlemler yetersiz, bu nedenle tedbir alınmalı şeklinde yorumlanır $[23,24]$.

\section{B3. Tehlike ve Risk Azaltıma Çalışmaları}

Risk analiz ve değerlendirme çalışmalarının sonrasında bu risk analizleri temel alınarak birim ve kurullar bazında tehlike/risk giderme ve azaltma çalışmaları başlamıştır. İSG çalışmalarının etkisiyle 2013-2017 yıllarında tehlikeli durumlardaki değişimler karşılaştırması Tablo 2'de ve risk puanlarındaki değişimler ise Şekil 2'de sunulmuştur.

Şekil 2: 2013-2017 yılları arasında DPÜ birimlerinde risk göstergelerindeki değişim.

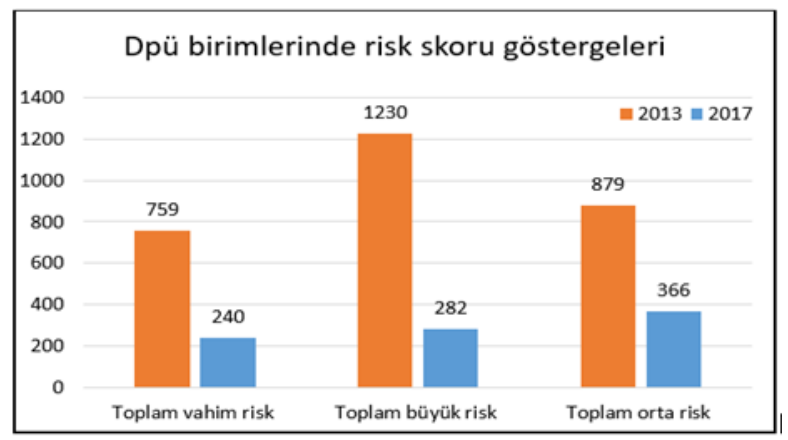

Birimlerde risklerin azaltılması ve giderilmesi amacıyla yapılan çalışmalar aşağıda özetlenmiştir.

- Güvenlik ve sağlık uyarı işaretleri ile ilgili ihtiyaçlar belirlenerek bu ihtiyaçların temini sağlanmış, birimlerce uygun yerlere konumlandırması yapılmıştır.

- Yangın söndürme cihazları (YSC) kontrol edilmiş, yangın yönetmeliğine uygun miktarda temin edilerek uygun yerlere asılmıştır. 
Tablo 2: 2013-2017 yıllarında Kütahya DPÜ çalışma ortamında tespit edilen tehlikeler, kaynağına göre dağılımı ve değişimlerinin karşılaștırılması.

\begin{tabular}{|c|c|c|c|c|c|}
\hline \multirow{2}{*}{ 3T Risk Değerlendirme Yöntemi Modülleri } & & & \multicolumn{3}{|c|}{ Tehlikeli Durum Sayıları } \\
\hline & Harf & Renk & $\begin{array}{c}2013 \\
\text { Tespit Edilen }\end{array}$ & İyileştirilmiş & $\begin{array}{l}2017 \\
\text { Kalan }\end{array}$ \\
\hline Kazalara yol açabilecek tehlikeler & A & & 483 & 366 & 117 \\
\hline Çalışma ortamındaki fiziksel tehlikeler & B & & 74 & 41 & 33 \\
\hline Çalışma ortamındaki kimyasal ve biyolojik tehlikeler & C & & 379 & 301 & 78 \\
\hline Yapılan işin kas-iskelet sistemine yaptiğı baskılar & $\mathrm{D}$ & & 97 & 61 & 36 \\
\hline Yapılan işteki psiko-sosyal stres faktörleri & $\mathrm{E}$ & & 88 & 84 & 4 \\
\hline İç nakliye ve taşıma & $\mathrm{F}$ & & 13 & 12 & 1 \\
\hline Bina ve çevresi genel trafikte araç kullanma & G & & 5 & 5 & 0 \\
\hline Makineler ve el aletleri & H & & 93 & 46 & 47 \\
\hline Yangın ve patlamalara karşı güvenlik önlemleri & 1 & & 688 & 469 & 221 \\
\hline Çevresel konular & $\mathrm{J}$ & & 3 & 0 & 3 \\
\hline İş yerindeki güvenlik ve çalışma kültürü & K & & 25 & 22 & 3 \\
\hline Bina ve iş yeri tesisleri & L & & 159 & 142 & 17 \\
\hline Kurulum ve bakım çalışması & M & & 204 & 201 & 3 \\
\hline İş sağ|ığı hizmetleri & $\mathrm{N}$ & & 35 & 32 & 3 \\
\hline
\end{tabular}

- Kazan daireleri ve basınçlı kapların periyodik bakımları yapılmış, kazan sorumlularına eğitim verilerek yetkinlikleri sağlanmıştır.

- Tüm üniversite bünyesinde elektrik tesisatları ve panoların kontrolü yapılmış, eksik olan kaçak akım röleleri takılmıştır.

- Personel odaları ile ortak çalışma ortamlarındaki düşme sonucu risk oluşturabilecek dolapların duvarlara sabitlendiği Şekil 3'te gösterilmiştir.
Şekil 3: Risk oluşturabilecek dolapların duvara sabitlenmesi.

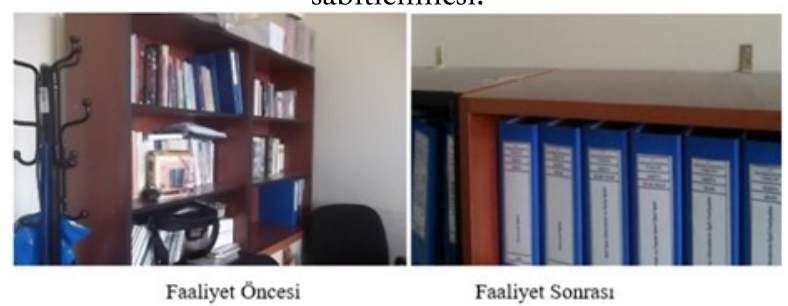

- Gerekli görülen korkuluk ve tırabzan eksikleri giderilmiş yükseklikleri uygun hale getirilmiştir.

- Tüm merdivenlere kaydırmaz bantlar çekilmiş olup, 
yetersiz acil çıkışı olan binalara yönetmeliğin öngördüğü sayıda ve uygun yerlere yeni acil çıkış kapıları yapıldığı Şekil 4’te gösterilmiştir.

Şekil 4: Merdivenlere kaydırmaz bant uygulaması, acil çıkışların yeniden düzenlenmesi.

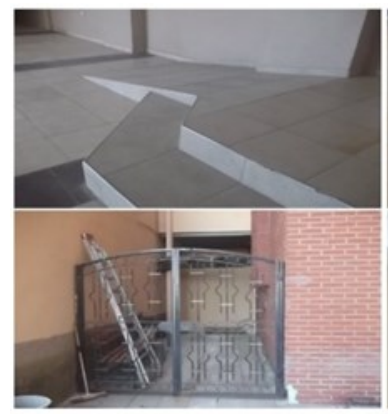

Faaliyet Öncesi

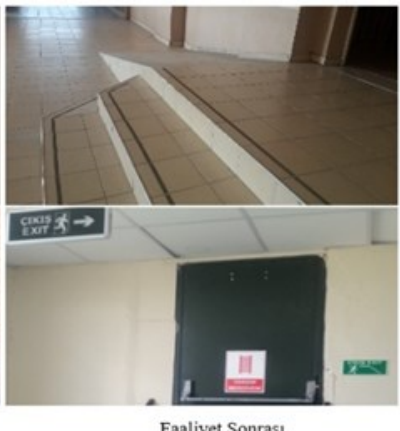

Faaliyet Sonrası
- Saha gözetimi sonucunda gerekli görülen uyarı işaretçileri yerleştirilmiş, düzensizlikler giderilmiştir.

- Çalışanlar ve idareciler Kişisel Koruyucu Donanımları (KKD) kullanımının önemi hakkında bilinçlendirilmiş ve eksik KKD’nin temini ve uygun şekilde kullanılması konusunda gerekli uyarı ve bilgilendirilmelerin yapıldığı Şekil 5’te gösterilmiştir.

Şekil 5: Saha gözetimi sonrası uyarı levhalarının asılması, güvenlik işaretlerinin yerleştirilmesi.

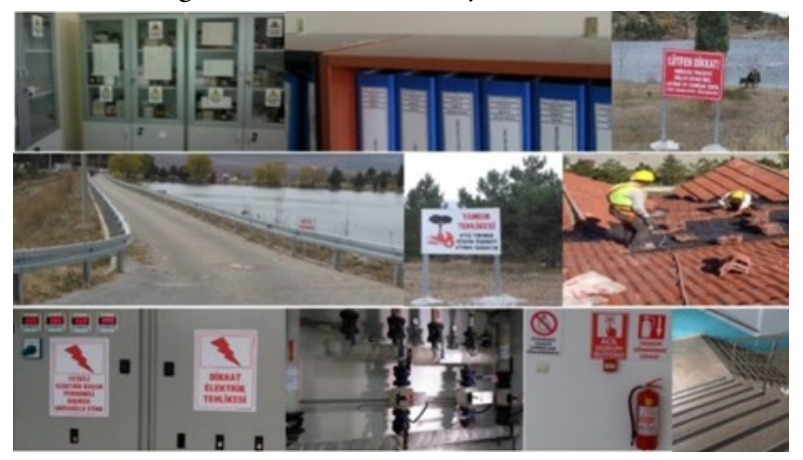

- Tehlikeli kimyasal madde (patlayıcı, yanıcı, zehirli, radyoaktif, aşındırıcı vb.) bulunduran her bölüm için kullanım, depolanma, korunma, önlem ve müdahale boyutuyla ilgili Malzeme Güvenlik Bilgi Formları (MSDS) hazırlatılmışırı. Tehlikeli kimyasal maddelerin bulunduğu yerlere gerekli işaretlemeler asılmış ve bu alanlarda çalşsanlara bilgilendirmeler yapıldığı Şekil 6'da gösterilmiştir.

Şekil 6: Saha gözetimi sonrası kimyasal malzemelerin depolanması ve etiketlenmesi.

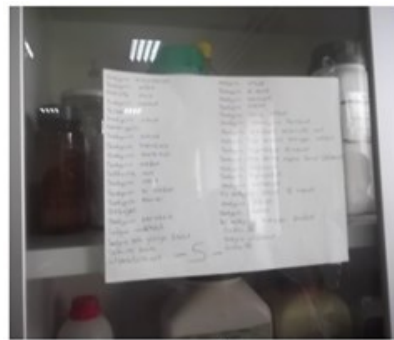

Faaliyet Öncesi

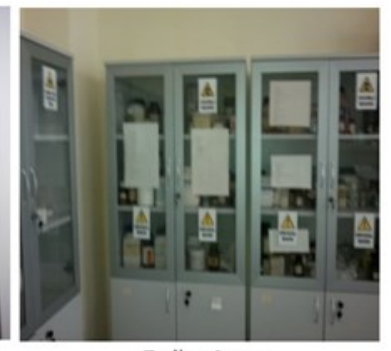

Faaliyet Sonras!
- İş ekipmanlarının periyodik bakımları ve fiziksel, biyolojik ve kimyasal risk etmenleri için ortam ölçümlerinin yönetmeliğe uygun olarak yapılması sağlanmıştır. Konu ile ilgili olarak birimlere gerekli uyarı ve bilgilendirmeler; iş sağlığı ve güvenliği kurullarında, iş güvenliği uzmanlarının saha çalışmaları sonrasında eksiklikler onaylı deftere kaydedilerek, konuyla ilgili gerekli çalışmalar başlatılmışır.

- 26/12/2003 tarih ve 25328 sayılı Resmi gazetede yayımlanarak yürürlüğe giren iş yerlerinde oluşabilecek patlayıcı ortamların tehlikelerinden çalsşanların sağlık ve güvenliğini korumak için alınması gerekli önlemleri içeren "Patlayıcı Ortamların Tehlikelerinden Çalışanların Korunması Hakkında Yönetmelik” in 10. maddesi gereği işverenler için patlamadan korunma dokümanı hazırlanması gerekmektedir. Yönetmeliğe göre patlamadan korunma dokümanı hazırlanması gereken ortamlara yönelik olarak ilgili birimlere gerekli uyarı ve bilgilendirmeler yapılmış, konuyla ilgili gerekli çalışmalar başlatılmışır [25].

- Birimlerdeki tüm makine ve ekipmanların temin, depolama, kullanım ve bakım talimatlarının hazırlanması, gerekli bilgilendirmelerin yapılması ve uygun yerlere asılması konularında birimlere gerekli uyarı ve bilgilen- 
dirmeler yapılmış, konuyla ilgili gerekli çalışmalar başlatılmıştır.

- Binaların yangından korunması hakkındaki yönetmeliğe uygunluğu değerlendirilip, binalarda yapılması gereken tadilat, tamirat, düzenleme, periyodik bakım ve kontrol planlamalarının ivedilikle yapılması konusunda birimlere gerekli uyarı ve bilgilendirmeler; iş sağlı̆ğ ve güvenliği kurullarında, iş güvenliği uzmanlarının saha çalışmalarından edindikleri gereklilikler onaylı deftere yazılarak yapılmıştır.

- Binaların deprem yönetmeliğine uygunluğu değerlendirilip, eylem planlarının ivedilikle hayata geçmesi noktasında birimlere gerekli uyarı ve bilgilendirmeler; iş sağlığı ve güvenliği kurullarında, iş güvenliği uzmanlarının saha çalışmalarında ve onaylı deftere yazılarak yapılmıştır. Deprem yönünden riskli olduğu değerlendirilen binalar için karot örnekleri alınarak gerekli test ve incelemelerin yapılması konusunda gerekli yazışmalar başlatılmıştır.

- Alt işverenlerin İSG kapsamındaki yükümlülükleri resmi yazışma evrak takibi ve saha çalışmalarıyla sürekli takip edilmekte ve denetlenmektedir. Bu takip ve gözetiminin sağlıklı bir şekilde yapılabilmesi için kontrol listeleri ve formları düzenlenmiş, asıl ve alt işverenlere gerekli uyarı ve bilgilendirmeler yapılmıştır.

2013 yılında risk analizleriyle belirlenen tehlike ve risklere paralel olarak dinamik ve sürekli (anlık) tehlike ve risklerin tespit edilmesi, tespit edilen hataların giderilmesi, sonuçlarının takibi amacıyla Düzeltici Önleyici Faaliyet (DÖF) listesi hazırlanmıstır. DÖF listeleri ile üniversite yerleşkesinde yaşamı paylaşan tüm bireyler (çalışanlar, alt işveren çalışanlar ve öğrenciler) İSG kültürünün gelişimine ve risklerin giderilmesine katkı sağlamaktadır. DÖF talebi, DÖF formu ile yapılıp, uygunsuzluğun olduğu birim so- rumlusuna teslim edilmekte bu şekilde riskin giderilmesine yönelik süreç başlamaktadır. Birimler DÖF’lerin takibini düzeltici ve önleyici faaliyet takip formu ile yaparlar. Birimler DÖF faaliyetleri neticelerini iş sağlığı ve güvenliği koordinatörlüğüne bildirip, iş sağlı̆̆ı ve güvenliği koordinatörlüğünde toplanan tüm DÖF bildirimleri değerlendirilerek, İSG üst kurul gündeminde üst yönetime (işverene) sunulur. 2015-2017 yılları arası DPÜ iş sağlığı ve güvenliği koordinatörlüğü DÖF analiz raporuna göre hazırlanan veriler Tablo 3'te sunulmuştur [26].

Tablo 3'te görüldüğü gibi birimlerin DÖF listelerini etkin olarak kullandığı ve anlık karşılaşılan tehlike ve risklerin etkili ve hızlı bir şekilde giderilmesinde ciddi katkı sağladığı anlaşılmaktadır.

Tablo 3: 2015-2017 yıllarında açılan ve kapanan DÖF'ler.

\begin{tabular}{cccc}
\hline \multicolumn{2}{c}{ 2016 Yılı DÖF } & 2017 Yılı DÖF \\
\hline Açılan & 92 & Açılan & 19 \\
Kapanan & 22 & Kapan & 12 \\
Devreden & 70 & Devreden & 7 \\
& & Toplam devreden & 77 \\
\hline
\end{tabular}

Üniversite çalışma alanlarında ortaya çıkan tehlike ve risklerin giderilmesinde öncelikle birimler kendi teknik kapasite ve imkânlarıyla bu riskleri gidermeye çalışmakta, birim imkânlarının yetersiz olduğu durumlarda ilgili tehlike ve risk yapı işleri daire başkanlığınca giderilmektedir.

\section{B4. Hazırlık}

Tehlike/Risk tespit ve azaltma çalışmaları sonrasında geriye kalan risklerin geçekleşme durumuna karşı hazırlık çalışmaları yapılır. Gerçekte hazırlık çalışmaları acil durum oluşturan kaza veya afet sonrasında hayata geçirilecek eylemlerin planlarının yapıldığı aşamadır. Etkin müdahalenin temelinde detaylı hazırlanmış ve test edilmiş hazırlık planlarının vardır. Bu çerçevede, Kütahya DPÜ'de Acil Durum Planları birim ve bina bazında hazırlanarak tamamlanmış- 
tır. Planların test edilmesi ve uygulama etkinliğinin arttırılması için büyük önem taşıyan tatbikatlar ise, yönetmeliğin öngördüğ̈̈ zaman aralıklarıyla birimlerde hayata geçmektedir.

\section{EĞİTİMLER}

Etkin risk yönetiminde şüphesiz en önemli araçlardan biri İşs sağlığı güvenliği kapsamında yürütülen eğitim faaliyetleridir. Üniversitemiz bünyesinde 2015 yllından bugüne İş Sağlığı Güvenliği kapsamında yürütülmüşs ve yürütülmekte olan eğitim faaliyetleri aşağıda özetlenmiştir.

a. Görev yapmakta olan personelin temel İSG eğitimleri 3 senede bir yenilenmek üzere iş güvenliği uzmanları tarafından verilmektedir. Her ne kadar Üniversiteler az tehlikeli iş grubu olarak tanımlanmışsa da verilen çalışan eğitimlerinde birimlerde yapılan işin tehlike boyutu dikkate alınmış, bu tehlike özelliğine göre eğitimler az tehlikeli (8 saat) tehlikeli (12 saat) ve çok tehlikeli (16 saat) sınıfta verilmiştir. Bu kapsamda bugüne kadar 2350 personele eğitim verilmiş olup, eğitimsiz personel bulunmamaktadır.

b. Yeni işe başlayan, 6 aydan fazla işinden uzak kalan, iş kazası geçiren veya kadrosu değiștirilerek işyeri değişen personele ișbaşı eğitimi sistematik olarak verilmektedir. İş güvenliği uzmanları tarafından tehlike sınıfına ve yönetmeliğe uygun İşbaşı eğitimi verildiği belgelenen personele katılım belgesi verilmektedir.

c. Birimlerin acil durum planlarında ilkyardım, arama kurtarma ve yangına müdahale ekiplerinde görevlendirilen destek personelin $\underline{\text { ilkyardım, arama kurtarma ve }}$ yangına müdahale eğitimlerini almaları sağlanmıştır. Yangın yönetmeliği ve İsyyerlerinde Acil Durumlar Hakkında Yönetmelikte belirtilen personel oranları dikkate alınarak 115 personele ilkyardım eğitimi DPÜ ilkyardım merkezince, 160 personele arama kurtarma eğitimi ve 170 personele yangına müdahale eğitimi Kütahya DPÜ Afet ve Acil Durum Yönetimi Eğitim Uygulama ve Araştırma Merkezi (AFAMER) tarafından verilmiş, tüm eğitimler sertifikalandırılmıştır.

d. Hijyen eğitimi 29 personele DPÜ AFAMER sorumluluğunda yetkin eğitmenler tarafından verilmiş sertifikalandırma yapılmışır.

e. İnşaat sektöründeki iş kazaların önlenmesinde kritik önem sahip olan yüksekte çalıșma eğitimleri Kütahya DPÜ AFAMER tarafından yetkin eğitmenler tarafından verilmiş, 62 personel sertifikalandırılmıştır.

f. Mesleki Yeterlilik Kurumu tarafından tanımı yapılmış meslekler için ilgili meslekleri Üniversite bünyesinde yapacak personele yönelik olarak gerekli yetkinlik eğitimlerinin alınması konusunda ilgili birimlere gerekli bilgilendirme ve uyarılar yapılmış, konu hakkında çalışanlarda ve idarecilerde farkındalık sağlanmışır.

g. Alt işveren çalışanlarının mesleki yeterlilikleri ve çalışma ortamının gerektirdiği eğitimlerini almaları ve bu eğitimleri alabilecekleri merkezler konusunda gerekli bilgilendirme ve uyarılar yapılmıştır.

\section{KAZA YÖNETIMMİ ÇALIŞMALARI}

DPÜ Birimlerinde oluşan iş kazaları ve ramak kala olayları birim işveren vekili ve iş güvenliği uzmanı ile tutanak düzenlenerek 3 iş günü içinde $S G K$ ya bildirilmekte olup tutulan tutanağın bir nüshası İSG Koordinatörlüğüne iletilmektedir. Koordinatörlük Koordinasyon kurulunca iş kazası ve ramak kala olaylarının tutanakları değerlendirilmekte ve alınacak önlemler ve iyileştirme çalışmaları ile ilgili İSG Üst Kuruluna önerilerde bulunulmaktadır. İSG Üst Kurulunda alınacak önlemler ve iyileştirme çalışmaları ile ilgili kararlar tüm birimler tarafından uygulamaya geçi- 
rilmektedir. Türkiye genelinde 1975 'ten beri meydana gelen iş kazaları incelendiğinde endüstriyel büyümeye paralel bir artışın olduğu kaydedilmiştir. Bunun yanında 20162020 yıllarında bu artışın devam edeceği öngörülmekte olup, kaza yönetiminin etkinliği bütün kuruluşları yakından ilgilendirmektedir [27]

2015-2017 Yılları arasında DPÜ'de meydana gelen iş kazası ve ramak kala olaylar Tablo 4' te verilmiştir. Tablo incelendiğinde yaralanmalı iş kazalarında artış olduğu görülmektedir. Kaza sayısındaki artışın personel sayısı ve yapılan iş miktarıyla değerlendirilmesi doğru bir kıyaslama yapmamızı sağlayacaktır. Dolayısıyla 2017 yılında personel ve tehlikeli işlerde artış beraberinde iş kazalarının da artmasına neden olmuştur. Eş zamanlı artışa rağmen iş kazası oranının personel ve tehlikeli işe oranının az olmasının uygulamaya konulan İSG düzenlemeleriyle sağlandığı rahatlıkla söylenebilir. Kütahya DPÜ’deki iş kazalarının nedenleri incelendiğinde, Dünyada meydana gelen iş kazası nedenleriyle benzerlik gösterdiği ve eğitim, motivasyon, İSG kültürünü benimsetme-sevdirme yöntemleriyle aşılabileceği sonucuna varılmıştır.

Tablo 4: 2015-2017 Yılları arası DPÜ meydana gelen iş kazası ve ramak kala olayları

\begin{tabular}{|c|c|c|c|}
\hline & 2015 & 2016 & 2017 \\
\hline $\begin{array}{l}\text { Yaralanmalı } \\
\text { İş Kazası }\end{array}$ & 1 & 3 & 6 \\
\hline $\begin{array}{l}\text { Ölümlü } \\
\text { İş Kazası }\end{array}$ & - & - & - \\
\hline Sebepleri & \multicolumn{3}{|c|}{$\begin{array}{l}\text { - Dikkatsizlik, } \\
\text { - Tedbirsizlik, } \\
\text { - Periyodik bakım eksikliği } \\
\text { - Uygun KKD kullanmama } \\
\text { (Meydana gelen olay; yüksekten düş- } \\
\text { me, kesici /hareketli alet yaralamaları }\end{array}$} \\
\hline $\begin{array}{l}\text { Ramakkala } \\
\text { Olaylar }\end{array}$ & 1 & 0 & 3 \\
\hline Sebepleri & \multicolumn{3}{|c|}{$\begin{array}{l}\text { - Dikkatsizlik, } \\
\text { - Tedbirsizlik, } \\
\text { - Periyodik bakım eksikliği }\end{array}$} \\
\hline
\end{tabular}

\section{SONUÇ, TARTIŞMA VE ÖNERİLER}

Bu çalışmada 6331 sayılı İş Sağlığı ve Güvenliği Kanunu kapsamında kamu kurumlarında yürütülmesi gerekli görülen iş sağlığı güvenliği uygulamaları konu alınmıştır. Henüz İSG Kanunun Kamu Kurumlarında yürürlüğe girmeyen 6. ve 7. (dolaylı olarak 8.) maddelerini kapsayan İSG hizmetlerinin Kütahya Dumlupınar Üniversitesindeki uygulamaları derlenmiştir. Kütahya DPÜ İSG birimi tarafından yürütülen İSG hizmetlerinin uygulanmasından önce ve sonrasındaki durum $3 \mathrm{~T}$ risk analizi bulgularına göre nitel değerlendirme yöntemiyle incelenmiştir. İSG birimlerinin yapılanması, idari düzenlemeler, eğitim faaliyetlerine yer verilmiştir.

Bünyesinde çok tehlikeli ve tehlikeli grupta yer alan işyerlerinin ana faaliyet alanlarından örnekler bulunduran Üniversitelerde İSG uygulamaları önem arz etmektedir. Çalışan sayısının en az 500 ve üzerinde olmasının yanında tehlikeli işlerin yapıldığı birimler içermesi Üniversitelerde İSG hizmetleri için kendine has bir yaklaşım modelini zorunlu kılmaktadır. Her bir faaliyet alanındaki tehlikelerin kontrol listesi mantığına göre değerlendirildiği 3T modelinin Üniversitelerde oldukça kullanışı bir risk analizi yöntemi olduğu sonucuna varılmıştır. 3T modeli kullanılarak yapılan değerlendirmeler sonucunda ofislerde, inşaat alanlarında, merdivenlerde, yürüyüş ve araç yollarındaki riskler ve uygunsuzluklar belirlenerek, çözüm önerileri sıralanmıştır.

Kamu sektöründe 1 Temmuz 2020'de yürürlüğe girecek olan risk değerlendirmesi, uzman ve sağlık personeli bulundurma zorunluluğu gibi temel İSG uygulamaları Kütahya DPÜ'de 2013'ten itibaren kademeli olarak uygulanmaya başlanmıştır. Böylece DPÜ Rektörlüğü ve birimlerince yüksek bir özveriyle yürütülen çalışmalar neticesinde, iş sağlığı ve güvenliği kültürünün oluşması adına pozitif 
bir iklim ve farkındalık oluşturulmuştur. Bu durum çok sayıda çalışanın olduğu bir çalışma ortamı için büyük önem taşımakta ve diğer kamu ve özel sektörde faaliyet gösteren işyerleri için İSG işlerinde fikir verici ve yol gösterici bir rehber niteliğindedir. İSG işlerinin uygulanmasında karşılaşılan sorunlardan bazıları ve bu sorunlara öneriler şu şekilde tespit edilmiştir:

- İSG-KATİP’te kamu kurumları modülünün oluşturulmaması, iş sağlığı ve güvenliği çalışmalarının kontrol mekanizmasında boşluğa neden olmakta, bu durum işveren vekilleri ve çalışanlarda bu hizmetlerin öneminin farkına varmalarını zorlaştırmaktadır.

- Kamu sektörünün iş sağlığı ve güvenliği çalışmalarında İSG-KATİP üzerinden veya başka modüllerden, raporlar, planlar, talimatlar, takipler ve diğer konularda, işveren, işveren vekilleri, işyeri hekimi ve iş güvenliği uzmanlarının kullanabileceği yazılım geliştirilmesi veya önerilmesi İSG hizmetlerinin daha etkin yürütülmesinde fayda sağlayacaktır.

- Kamu kurumlarında görevlendirmeyle çalışan iş güvenliği uzmanları ve işyeri hekimlerine ek iş yükü verilmeden görev yapmaları İSG profesyonellerinin çalışma performansını arttıracaktır. Bunun için kamuda iş güvenliği uzmanı ve işyeri hekimi kadrosu tahsis edilmesi uygun çözüm olabilir.

- Ortak bir iş güvenliği kültürünün oluşumu ve birlikteliğin sağlanması adına, sektörel/tehlike sınıfı/bölgesel vb. bazda yapılacak çalıştaylar iş sağlığı ve güvenliği hizmetlerini geliştirici ve iyileştirici yönde katkı sağlayacaktır.

- Yürütülen eğitim ve saha çalışmalarıyla güvenlik kültürünün gelişiminde yol kat edilse de yönetici ve çalş̧anlarda güvenlik risklerine karşı olay meydana geldikten sonra kontrol altına alma yaklaşımı ağır basmaktadır. İş kazası meydana gelmeden önce çalısma yapmak ek maliyet, ek çalışma gücü ve zaman kaybı olarak algılanmaktadır. Kurumlarda her yönüyle proaktif çalışmayı teşvik edici tedbirlerin alınması ve uygulamaların yapılması büyük önem taşımaktadır.

\section{KAYNAKLAR}

[1] Mohajan, H.K. (2019). The First Industrial Revolution: Creation of a New Global Human Era. Journal of Social Sciences and Humanities, 5(4), 377-387.

[2] Şen Söğüt, C. (2018). İş Güvenliği Kültürü ve Üniversiteler. MCBÜ Soma Yüksekokulu Teknik Bilimler Dergisi, 25(1).

[3] Çiçek, Ö., \& Öçal, M. (2016). Dünyada ve Türkiye’de İş Sağlığı ve İş Güvenliğinin Tarihsel Gelişimi. Hak-İs Uluslararası Emek ve Toplum Dergisi, 5(11), ISSN: 2147-3668.

[4] Amponsah Tawiah, K., \& Dartey Baah K. (2011). Occupational Health and Safety: Key Issues and Concerns in Ghana. International Journal of Business and Social Science, 2(14), 119-126.

[5] Ceylan, H. (2012). Analysis of Occupational Accidents According to The Sectors in Turkey. Gazi University Journal of Science (GU J Sci), 25(4), 909918.

[6] Tok, E.G., \& Satır, B. (2018). Kamu Kurumlarında Risk Değerlendirmesi İçin Karar Destek Sistemi Önerisi. Sosyal Güvence Dergisi, (14), DOI: 10.21441/ sguz.2018.69

[7] SGK. (2017). SGK İstatistik Yıllıkları. Erişim Tarihi: 19.02.2020, http://www.sgk.gov.tr/wps/portal/sgk/ tr/kurumsal/istatistik/sgk_istatistik_yilliklari

[8] Mevzuatı Geliştirme ve Yayın Genel Müdürlüğü, 6331 Sayılı İş Sağlı̆̆ ve Güvenliği Kanunu. Erişim Tarihi: 19.02.2020, https://www.resmigazete.gov.tr/ eskiler/2012/06/20120630-1.htm

[9] Yenisarı, B., Mestav, B., \& Öztürk, Ö.F. (2019). Üniversite Çalışanlarının İş Sağglığı ve Güvenliği Eğitimi Konusundaki Bilinç Düzeylerinin Araştırılması. Çanakkale Onsekiz Mart Üniversitesi Fen Bilimleri Enstitüsü Dergisi, 5(2), 339-355.

[10] T.C. Aile, Çalışma ve Sosyal Hizmetler Bakanlığı Genel yayın no:53. (2019). Kamuda-İş-Sağlığı-veGüvenliği-Rehberi.ISBN978-975-455-301-7, Ankara. 
[11] Yılmaz, S., Sezen, A., \& Ergül, C. (2015). 6331 Sayı$l_{1}$ İş Sağlığı ve Güvenliği Kanunu’ nun Sağlık Sektörüne Etkileri. Sağ Aka Derg (Sağlık Akademisyenleri Dergisi), 2(2).

[12] Yıldırım, S.A., \& Gerdan, S. (2017). Hastane Öncesi Acil Sağlık Çalışanlarının İş Sağlığı ve Güvenliği Kapsamındaki Mesleki Riskleri. Hastane Öncesi Dergisi (Hod),2(1), 37-49.

[13] Cereci, C. \& Çetin, R.B. (2019). İş Sağlığı ve Güvenliği Mevzuatından Kaynaklanan Sorumluluklarına İlişkin Okul Müdürü Görüşleri. Çağdaş Yönetim Bilimleri Dergisi, 2(6).

[14] Artvinli, F. (2016). The Ethics Of Occupational Health And Safety In Turkey: Responsibility And Consent To Risk. Acta Bioeth., 22(1), 111-118.

[15] Alli, B.O. (2008). Fundamental principles of occupational health and safety, Second edition, ISBN 97892-2-120454-1, Geneva.

[16] Can, G.F., \& Kargı, Ş. (2019). Sektörlerin İş Sağlığı ve Güvenliği Yönünden Risk Seviyelerinin CrıtıcEdas Entegrasyonu İle Değerlendirilmesi. Endüstri Mühendisliği, 30(1), 15-31.

[17] Altıntop, E. (2018). İş Sağlığı ve Güvenliği Hukuku Bakımından Kamu Kurumlarında İşveren Kavramı. Yüksek Lisans Tezi, Denizli

[18] Ghahramani, A., \& Salminen, S. (2019). Evaluating Effectiveness Of OHSAS 18001 On Safety Performance İn Manufacturing Companies In Iran, Journal of Safey Science, 112, 206-212.

[19] Demir, B., \& Demir, N. (2016). Kamu Sektöründe 6631 Sayılı İş Sağlığı Güvenliği Yasasının Uygulanması ve Mevcut Yükümlülükler. İstanbul Aydın Üniversitesi Dergisi, 29,167-194.

[20] Shalini, R.T. (2009). Economic cost of occupational accidents: Evidence from a small island economy, Journal of Safey Science, 47, 973-979.

[21] Gümüş, R., \& Gülsün, Z. (2017). Occupational health and safety indicators of Turkey and the irrelation ships with social and economic development factors between 1998 and 2014. International Journal of Healthcare Management, DOI:10.1080/20479700.2017.1308669.

[22] Demir, B. (2017). 6331 Sayılı Kanunun 6. Maddesi Yürürlülük Ertelenmesinin Kamuda İş Sağlığı Ve Güvenliği Uzmanı Çalıştırılması Açısından Değerlendirilmesi, Hastane Ö́ncesi Dergisi, 2(1), 23-36.

[23] Sarı, Y.D., Erdem, H., \& Dönmez, S. (2014). Mermer Sektörü İçin Uyarlanmış Yeni Bir Risk Değerlendirme Yöntemi. VII Uluslararası İş Sağlığı ve Güven- liği Konferansı Sunumu, İstanbul. Erişim Tarihi:19.02.2020,http://app.csgb.gov.tr/isggm/ oshaturkey/sunumlar/22.pdf

[24] Çakmak, E. (2016).28 Nisan 2016 Dünya İş Sağlığ1 ve Güvenliği Günü Sunumu. İzmir Ekonomi Üniversitesi 1. İş Sağlığı ve Güvenliği Sempozyumu, İzmir. Erişim Tarihi: 13.12.2019, https:// www.slideshare.net/ekremcakmak/zmir-ekonominiversitesi-1-sal-ve-gvenlii-sempozyumu-sunumu

[25] Kütahya Dumlupınar Üniversitesi İş Sağlığı ve Güvenliği Koordinatörlüğü, İş Sağlığı ve Güvenliği Uygulama Kılavuzu, 2018, Erişim Tarihi:15.01.2020, http://Birimler.Dpu.Edu.Tr/App/Views/Panel/ Ckfinder/Userfiles/143/Files/ _S_SAGLIGI_VE_Guevenl_G_UYGULAMA_KIL AVUZU.Pdf

[26] Mevzuatı Geliştirme ve Yayın Genel Müdürlüğü, Çalışanların Patlayıcı Ortamların Tehlikelerinden Korunması Hakkında Yönetmelik. Erişim Tarihi: 19.02.2020, https://www.resmigazete.gov.tr/ eskiler/2013/04/20130430-6.htm

[27] Ergül, B. (2018). Türkiye'deki İş Kazalarının Zaman Serisi Analiz Teknikleri ve Yapay Sinir Ağları Tekniği ile İncelenmesi. Karaelmas İş Sağlığı ve Güvenliği Dergisi, 2(2), 63-74. 